\title{
David Draper: The making of a South African geologist
}

\author{
Suryakanthie Chetty*
}

\begin{abstract}
David Draper was a South African geologist and key figure in the professionalisation of geology in the late nineteenth and early twentieth centuries. His biography demonstrates the importance of geology in South African political, economic and social history. This article traces Draper's life from the mid-nineteenth century to the mineral discoveries and the South African War in the early twentieth century. It uses the figure of Draper to show the complexities and tensions in the creation of a South African identity that were themselves reflective of the political and ideological struggles of a nascent nation. It further argues that the history of geology cannot be divorced from the history of the country, mirroring the processes of colonial domination, conflict and ultimately, the creation of an independent state.
\end{abstract}

Keywords: David Draper; geology; science; 1820 settlers; South African War; Geological Society of Southern Africa; imperial history; Molengraaff.

\section{Opsomming}

David Draper was 'n Suid-Afrikaanse geoloog en 'n sleutelfiguur in die professionalisering van geologie in die laat-negentiende en twintigste eeue. Sy biografie is ' $n$ aanduiding van die belang van geologie in Suid-Afrika se politiese, ekonomiese en sosiale geskiedenis. Hierdie artikel gaan Draper se lewe na, van die mid-negentiende eeu tot die ontdekking van minerale en die Suid-Afrikaanse Oorlog in die vroeg-twintigste eeu. Dit gebruik Draper se figuur om die kompleksiteite en spannings in die skepping van 'n Suid-Afrikaanse identiteit, wat sigself 'n refleksie is van die politiese en ideologiese stryd van die wordende nasie, te demonstreer. Dit argumenteer verder dat die geskiedenis van geologie nie geskei kan word van die geskiedenis van die land nie, aangesien dit die prosesse van koloniale dominasie, konflik en, uiteindelik, die skepping van 'n onafhanklike staat weerspiëel.

Sleutelwoorde: David Draper; geologie; wetenskap; 1820-setlaars; Suid-Afrikaanse Oorlog; Geologiese Vereniging van Suidelike Afrika; imperiale geskiedenis; Molengraaff.

* Suryakanthie Chetty is a senior lecturer in the Department of History, University of South Africa. She is currently conducting research into the history of geology in South Africa with a particular focus on Alex du Toit and continental drift. 
The history of geology as a discipline is a burgeoning field of historical research that has yet to be reflected substantially in South African historiography. The history of science in general in South Africa has been epitomised by the work of Saul Dubow who addresses the early history of geology in the nineteenth century with a particular emphasis on its implications for the formation of racial and national identity. ${ }^{1}$ The importance of empire and the creation of knowledge networks in the formation of identity is also alluded to by Barnard in his paper on Charles Darwin's brief stopover at the Cape, as are the eventual ideological repercussions of evolutionary theory which were buttressed by geology. ${ }^{2}$ Dubow also addresses the regional rivalry in the acquisition of knowledge about the natural environment and the establishment of various institutions and academic bodies. Similar to Dubow's work, Tanja Hammel's recent research demonstrates the importance of the Eastern Cape region in the development of natural history, ${ }^{3}$ an environment that had an important impact on David Draper.

Despite the lack of focus on geology, the field has underpinned much of the economic, social and political history of the country from the early days of colonial settlement to the upheaval wrought by the mineral discoveries in the late nineteenth century. The discipline has been linked inextricably to the fluid ideologies and identities that characterised the geographical entity that would become South Africa. Geology thus serves as a lens through which a nuanced history of the country can be articulated. This article focuses on David Draper, a key figure who straddled the worlds of the rough-hewn frontier amateur geologist and the consummate professional harnessing the earth's resources to the fledgling state. His professional career demonstrates both the complexity of national identity and its association with a discipline that was integral to the economic development of the state.

The article relies heavily on the unpublished and incomplete memoir penned by Draper himself. This source proved invaluable and stimulating in terms of the dramatic narrative. Written in an engaging and often light-hearted manner, it presents Draper as a larger-than-life figure who had some degree of involvement in the key historical events that led to the creation of a South African state and is a triumphalist tale of his rise to prominence from very humble beginnings. Simultaneously, the manuscript allows for an engagement with the ideological and intellectual worldview of Draper in terms of his position as a man grappling with the tensions of his identity in a newly emerging country and with a scientific discipline. His personal narrative thus allows insight into the larger historical narrative by which it is contextualised, while at the same time highlighting individual agency.

1. S. Dubow, A Commonwealth of Knowledge: Science, Sensibility and White South Africa, 1820-2000 (Oxford University Press, Oxford, 2007) p 102.

2. W.S. Barnard, "Darwin at the Cape", South African Journal of Science, 100 (May/June 2004).

3. T. Hammel, “Thinking with Birds: Mary Elizabeth Barber's Advocacy for Gender Equality in Ornithology", Kronos: Southern African Histories, 41, 1 (2015). 
Just two months before David Draper's death in September 1929, the British Association for the Advancement of Science paid a visit to South Africa, their first since 1905. This visit coincided with the holding of the 15th International Geological Congress in Pretoria - the first on the African continent (and in the southern hemisphere). The conference symbolised the growing assertion of scientific expertise in the southern hemisphere and the intellectual and political independence of the former colonies. In the address by Sir Albert E. Kitson, president of the Geological Section of the British Association of the Advancement of Science, both science and geology were harnessed to the colonial project and to the development needs of the fledgling settler states.

In their surveys of the landscape, geologists were the primary agents of acquiring knowledge of the uncharted interior. Early geologists travelled through rugged and hostile terrain, facing inclement weather; in no small measure they resembled early explorers facing the unknown. An important motivation was the quest for mineral wealth - untapped reserves of gold and other precious metals - but the geologist also functioned as the all-seeing eye that rendered the land knowable for the purposes of exploitation and domination:

The geologist is probably the only class of person who has to traverse large areas with his eyes open, not to one class of phenomena only ... He is led into ... many facts with regard to the distribution of animals and plants, and the dwellings, occupations and characteristics of the people can scarcely escape his observations; neither can he shut his eyes to historic and prehistoric facts. Thus a geologist is generally possessed of a store of knowledge reaching far beyond the strict bounds of his science. 4

This knowledge could be applied to agriculture, industrialisation, mining and settlement. As Kitson points out, the priority of geology in the new states was pragmatic - it was linked to the creation of infrastructure and development and essential for material prosperity. It also fostered military superiority through knowledge of the terrain for strategic purposes, provisioning and water supply. Less significant was the intellectual aspect, yet Kitson highlighted the tension that existed between the "practical" or amateur geologist - the early prospector responsible for the initial mineral discoveries - and the university-educated "scientific" geologist of the twentieth century who made use of scientific theory and methodology and an array of modern equipment to understand geological processes and, by so doing, predicted the location of resources. ${ }^{5}$ Kitson's address could function as an epitaph for the life and career of David Draper.

David Draper was born on 3 January 1849. He was the product of a second marriage between Thomas Draper and Eleanor Roach nee Loxton. The elder Draper

4. University of Cape Town, Jagger Library (hereafter UCT-JL), Du Toit Papers BC722, F2.5, Various Geological Aspects, Albert E. Kitson, "The Utility of Geological Surveys to Colonies and Protectorates of the British Empire", p 4.

5. Kitson, "The Utility of Geological Surveys", pp 4, 7, 16, 24. 
had been part of the contingent of British settlers who arrived in South Africa in 1820 . A widower, he left his native Yorkshire with his eight-year-old son - David's halfbrother - along with an assortment of other British settlers seeking their fortune in the Cape Colony. ${ }^{6}$ The arrival of five thousand British settlers in 1820 was impelled by the "civilising mission" of British imperialism. They were to be settled in the Zuurveld which had the effect of creating a bulwark between the Xhosa and the greater part of the expanding Cape Colony - although many of these settlers soon moved to the urban areas, Draper's father among them. As Legassick and Ross point out, these settlers also came to embody "an ideology of accumulation and dispossession" in their quest for land and resources. " "Civilisation" went hand-inhand with imperial and colonial domination and indigenous subjugation and it was Draper senior's inability to prosper and make the best of the opportunities afforded to him that created some sense of resentment in his son.

In his uncompleted autobiography, Draper has a romantic view of the 1820 settlers - he creates the impression of a hardy, independent group that singlehandedly tamed the South African wilderness and brought the benefits of civilisation. For his father that took on a literal meaning. Thomas Draper moved to Cape Town where he was placed in charge of the botanical gardens and also worked on the gardens of the colony's elite. He later did the same at the Grahamstown Botanical Gardens and the young Draper recalls watching his father planting trees and imposing order on the "tangle of weeds and scrub". 8 The creation of the Grahamstown Botanical Gardens was symbolic of a growing intellectual awareness in the border town and a corresponding intellectual rivalry with Cape Town. The midnineteenth century also saw the founding of St Andrew's College, the Albany Museum and the Literary, Scientific and Medical Society. ${ }^{9}$

Nor was this a solely male enterprise. Mary Elizabeth Barber, who had the unique distinction of being the first female South African ornithologist, was a toddler when her 1820 settler parents settled in South Africa. She lived and worked in Albany, a district of the Eastern Cape, making use of the collections at the Albany Museum and drawing upon the knowledge of indigenous groups such as the amaXhosa in her study of birds. ${ }^{10}$ Thomas Draper's role in the Grahamstown Botanical Gardens was therefore contextualised by a growing engagement with the natural history of the Eastern Cape. However, the devotion Thomas Draper lavished on horticulture was not extended to his family and David Draper criticised his father

6. Johannesburg City Library (hereafter JCL), J.P.L. Strange Collection MSA77, “Draper 577728”, D. Draper, "An Africander's Reminiscences” (unpublished and incomplete manuscript), p 2.

7. M. Legassick and R. Ross, "From Slave Economy to Settler Capitalism: The Cape Colony and its Extensions, 1800-1854", in C. Hamilton, B.K. Mbenga and R. Ross (eds), The Cambridge History of South Africa, Volume 1: From Early Times to 1885 (Cambridge University Press, New York, 2012), pp 269-270.

8. Draper, “An Africander's Reminiscences", pp 3, 6, 11.

9. Dubow, A Commonwealth of Knowledge, $\mathrm{p} 102$.

10. Hammel, "Thinking with Birds". 
for his inability to turn a profit and thus secure the family financially. This shortcoming meant that his mother had to work at a post office in Claremont and had a negative impact on the educational opportunities for the ambitious youngster. ${ }^{11}$ It was this financial insecurity that led to Draper's various economic activities as an adult and highlights the ways in which geology, in the South African context in particular, serves both pragmatic (economic) and intellectual interests.

Yet Thomas Draper also served to illustrate the role of the settlers in managing the landscape and rendering the inhospitable terrain familiar. It is therefore unsurprising that another settler who arrived in South Africa in 1820 was Andrew Geddes Bain who Draper describes in reverent terms as "the father of South African geology".12 As part of the development of the colony, Bain worked for the Royal Engineers Department and was involved in the building of roads that allowed him to access hitherto unexplored territory in the interior. After an interest in geology was awakened by reading Principles of Geology (1830) by Charles Lyell - a path that Draper himself later took - Bain was able to combine his enthusiasm for geology with road construction and he amassed numerous rock and fossil samples - many of them belonging to species long dead and unknown to science. He sent his discoveries to the Geological Society of South Africa and even penned a paper entitled "On the Geology of Southern Africa" that was accompanied by a geological map - one of the earliest to be charted of the region. Like Draper, Bain had no formal training in geology and his expertise was learnt in the field - a product of enthusiasm and opportunity. ${ }^{13}$ Grahamstown and the Eastern Cape also featured prominently in the development of geology in the mid-nineteenth century, with early geologists including Bain, Richard Rubidge and William Atherstone, the "Eastern Cape men" who regularly reported their geological and fossil discoveries in the Eastern Province Monthly Magazine. Atherstone also confirmed the first diamond found at Hopetown that ushered in a new era in South African geology and he was later tasked with investigating the possibility of gold deposits in the Karoo. ${ }^{14}$

The field of geology is integral to any study of colonialism in southern Africa; geology is intertwined with the search for mineral resources. Shortly after the arrival of employees of the Dutch East India Company and the establishment of a settlement at the Cape of Good Hope, Governor Simon van der Stel sent the first explorers into Namaqualand to search for copper. While ultimately the inhospitable terrain deterred mining efforts, Van der Stel's actions were a harbinger of what was to come. Exploration into the southern African interior accompanied by expanding colonisation also promoted the acquisition of geological knowledge with descriptive accounts and rock and fossil samples being sent back to the metropole. Geology was both the precursor and product of an expanding empire as evident in the letters of

11. Draper, “An Africander's Reminiscences”, pp 4, 9.

12. Draper, “An Africander's Reminiscences”, p 18.

13. A.W. Rogers, "The Pioneers in South African Geology and their Work", Transactions of the Geological Society of South Africa, Annexure to Volume XXXIX (Geological Society of South Africa, Johannesburg, 1937), p 19.

14. Dubow, A Commonwealth of Knowledge, pp 102-103. 
Captain Basil Hall describing Table Mountain which were presented before the Royal Society of Edinburgh in 1813. Hall was following in the footsteps of his father, James Hall, a geological pioneer who had worked alongside James Hutton, the founder of the modern discipline of geology. ${ }^{15}$

In 1836 Charles Darwin landed at Simons Bay and was given a geological tour of the region by the head of the South African Museum, Dr Andrew Smith. ${ }^{16}$ With Lyell's Principles of Geology in hand, Darwin had come to the hardly flattering conclusion that geology would provide the easiest way into the natural sciences for a novice. He collected geological samples assiduously in the course of his voyage on the HMS Beagle. Despite this, his notes reflect little that he found noteworthy of the natural environment, but he did recognised the Cape as forming a strategic point in the knowledge system of empire. ${ }^{17}$ While the experience may not have contributed substantially to Darwin's intellectual views, the same cannot be said for the effects of evolution theory on the intellectual philosophies of the Cape. In the years following the publication of The Origin of the Species (1859) and The Descent of Man (1871), evolution was combined with settler views of race to influence both political and intellectual thinking. ${ }^{18}$ Geology was central to this. As Dubow has shown, geology underpinned the fields of anthropology and archaeology. By directly raising questions about the age of the earth and prehistoric life, geology was linked to understandings of evolution and race that were themselves contextualised by the tensions in Cape society and within the British Empire itself. ${ }^{19}$ By the time of Draper's birth, then, South African geology had aroused considerable interest as part of the knowledge of empire - which increased immeasurably by the mineral discoveries in the ensuing decades.

Draper's early education was both eclectic and prematurely suspended. During his early years in Grahamstown he first attended the small local government school. Located in High Street, the school was situated in a large, low shed. Space and writing material were both at a premium and students learned their basic penmanship using sandboxes as desks. The headmaster, a Mr Tudhope had a keen interest in science and conducted experiments in electricity and magnetism for the gratification of his young charges. A short spell at this school was followed by an even shorter one in a school headed by the schoolmaster who provided tuition for the Cape Mounted Rifles that catered mainly for "Hottentots". A more promising start at St. Andrews College - established in 1855 - once again came to naught when the young Draper was stricken with rheumatic fever. ${ }^{20}$

15. Rogers, The Pioneers in South African Geology, $\mathrm{p} 7$.

16. Rogers, The Pioneers in South African Geology, p 15.

17. Barnard, "Darwin at the Cape", pp 243-245.

18. D. Livingstone, "Debating Darwin at the Cape", Journal of Historical Geography, 52 (2016), p 2.

19. S. Dubow, "Earth History, Natural History and Prehistory at the Cape", Comparative Studies in Society and History, 46, 1 (January 2004), p 109.

20. Draper, “An Africander's Reminiscences”, pp 11-12. 
Draper's illness was attributed to the climate and he was subsequently dispatched to the more arid Karoo to the town of Colesberg where his older stepbrother had established himself as a prosperous businessman. ${ }^{21}$ The journey took three weeks by ox wagon and it was during this sojourn that Draper began to take an interest in the unique rock formations in the area. He notes in his reminiscences:

To me it was a land of wonders. The fantastic shapes of the hills with their symmetrical slopes and crag crowned summits caused me to wonder whether they were natural or artificial. One hill resembled an inverted humming top, another the upper portion of an old-fashioned tea caddy (this hill is called "Theebus", the Dutch term for tea-caddy). Symmetrical cones were common and frequently two cones were connected by a gracefully curved saddle back. Had the country been the playground of Titans who had moulded the hills to suit their fancy, there could not have been a more fantastic variety of shapes in view. 22

His education continued its haphazard course at Colesberg, first in the village of Fauresmith where the focus was on the pious but impractical skills of hymnsinging until the teacher was removed from his position; and then at the ambitiously named "Fosseysfontein Academy", a school established on the farm of Fosseysfontein. This school was run by a headmaster notoriously enamoured with whisky and brandy who employed his students in the fine art of building stone enclosures to house his flock of sheep while he provided limited lessons in English and French. The experience did, however, allow Draper to collect the agates that littered the banks of the Orange River. ${ }^{23}$ A brief stint at Colesberg's government school marked the end of Draper's education at the age of thirteen when he was employed in his brother's store and made responsible for his own upkeep. His education - which he considered deficient in mathematics and grammar - was now to be pursued in his spare time and based on his own initiative. ${ }^{24}$

David Draper's youth and early life was contextualised by a period of exploration and with it, the acquisition of knowledge from people of European descent about southern Africa. Theoretically, the onset of imperialism and the scramble for Africa had opened up the continent to explorers who braved the unknown for motives as pecuniary as gold or as noble as the ending of slavery on the continent. Draper remembered being taken as a child to a talk given in Claremont by a gaunt, dark-haired man who spoke of finding an incredible waterfall further north. He was none other than David Livingstone, considered one of Africa's greatest explorers, who had named the Victoria Falls, the culmination of a journey that was almost mythical for its hardship. Just a few decades later, at the time of Draper's writing, a trip to Victoria Falls could be booked in Johannesburg and lasted less than a week, including return journey. ${ }^{25}$

21. Draper, “An Africander's Reminiscences”, p 14.

22. Draper, “An Africander's Reminiscences”, p 17.

23. Draper, “An Africander's Reminiscences”, pp 24-32.

24. Draper, "An Africander's Reminiscences”, p 32.

25. Draper, “An Africander's Reminiscences”, p 22. 
In Draper's youth, then, the natural history of southern Africa provoked both speculation and fascination. On his journey across the Karoo to Colesberg, he displayed a curiosity in the origins of the San people who still lived in the caves of the region. He speculated on their origins, drawing upon an eclectic mix of myth and social Darwinism, hazarding a guess that they may have been a lost tribe of Atlantis that had subsequently "devolved". For him, their origin was clearly not in Africa due to their marked distinctiveness from the "negro", their mental acuity and their easy acquisition of skills. Yet, he argued, their physical inferiority disadvantaged them in the evolutionary struggle for survival and had led to their adoption of cunning and vice. Draper also had great admiration for the landscape of the area; it became a site of wonder and he credits the work of Bain for unearthing the geological history of the Karoo - a region once far more temperate and marked by lush vegetation and water, a past world that was now only recorded in the fossil evidence. ${ }^{26}$ In Draper's curiosity about the San, he was preceded by Atherstone who hypothesised that these indigenous people had their origin in the antediluvian past, mirrored by the antiquity of the landscape that surrounded them. For Atherstone, they were "chattering races of the rocks" that could potentially provide insight into the evolutionary past. ${ }^{27}$

Draper's interest in geology became more practical once his formal education had ended. At the age of fifteen he left his brother's employ, dashing any fraternal hopes of a lifetime of storekeeping, to work for a sheep farmer. The period served as a form of apprenticeship and Draper also acquired other useful skills from making shoes and candles to preparing dried fruit. Yet, this also provided the opportunity for him to indulge in what he had yet to consider a prospective career - geology. ${ }^{28}$ As he worked on the farm, he took the opportunity to study the rocks that lay around, looking at their diverse structure and attempting to determine the reasons for this. Gazing at the hills around him, he pondered their origins, surmising that they may have once been the remains of higher ground that had since eroded through the processes that he could see around him such as the action of rain. The hills themselves were topped with more resistant rock that was less susceptible to erosion. ${ }^{29}$ Although he did not as yet know it, Draper's observations and applications of present processes to past events was an echo of Charles Lyell's uniformitarianism. At the time, though, it marked an insatiable curiosity about geological processes and the natural history of the earth.

Draper's musings were ended abruptly by conflict. King Moshoeshoe of the Basotho had been harried by increasing Boer incursion into his territory in their desire for the prime farming land west of the Caledon Valley. Moshoeshoe found himself engaged in warfare with Boer commandos drawn from the Orange Free State

26. Draper, “An Africander's Reminiscences”, pp 18-19.

27. Dubow, A Commonwealth of Knowledge, $\mathrm{p} 104$.

28. Draper, "An Africander's Reminiscences”, pp 36-37.

29. Draper, “An Africander's Reminiscences”, pp 38-39. 
and the Transvaal. ${ }^{30}$ With the resumption of hostilities, Draper - now of age - joined a commando under Jacobus Pansegrauus comprising some eighty men (both white and coloured). Here, the geology worked against them. The mountainous topography with its lofty peaks and steep ravines was a hostile landscape that was well suited to ambush by indigenous inhabitants more familiar with the terrain. This was nevertheless a fertile land and fully cognisant of this, the commandos carried out a war of attrition, seizing the Basotho's livestock and burning their reserves of grain. When the conflict finally ended, the land captured by the commandos became the basis for the Orange Free State's agricultural output of cereals. ${ }^{31}$

The end of the conflict with the Basotho marked a period of restlessness on the part of Draper; he sought a means to make his fortune. A brief foray into sheep farming ended in disaster when his flock was decimated by drought. However, at the time southern Africa was about to undergo a dramatic transformation that would make an indelible impact on the socio-political and economic structure of the country. The basis of this transformation was set in motion billions of years earlier.

Kimberlite pipes take their name from Kimberley, the South African city most associated with diamond mining and, until the acceptance of plate tectonics in the 1960s, these pipes were considered the key source of diamonds. Shooting up from the depths of the earth in volcanic eruptions, subject to high temperature and pressure, it was believed that they provided the ideal conditions for the metamorphosis of run-of-the-mill carbon into glittering, adamantine diamonds. Unsurprisingly, it was a geologist at the University of the Witwatersrand, Tom Clifford, who realised that kimberlite pipes derived from cratons - very ancient and stable segments of the earth's crust - that were diamond bearing. Prior to his discovery, and for much of the history of diamond mining in South Africa, all kimberlite pipes were investigated in the hope - often in vain - that they contained diamonds. ${ }^{32}$ It was in 1866 near Hopetown in the Cape Colony that a child was seen playing with a shiny rock and upon close scrutiny and further investigation it turned out to be a diamond. Several more alluvial diamonds were discovered subsequently but these were perceived to be isolated incidents and it was only when the first nonalluvial diamonds were found on the nearby Boer farms of Bultfontein and Dutoitspan situated between the confluence of the Vaal and Orange rivers that the diamond rush truly began with thousands of prospectors setting up rudimentary camps. ${ }^{33}$

Draper was not immune to the diamond rush. Along with a business partner, he first took up diamond mining on the Vaal River diamond fields, followed by a year

30. N. Etherington, P. Harries and B.K. Mbenga, "From Colonial Hegemonies to Imperial Conquest, 1840-1880", in Hamilton, Mbenga and Ross (eds), The Cambridge History of South Africa, Volume 1, p 369.

31. Draper, “An Africander's Reminiscences", pp 44, 47, 49.

32. N. Norman, The Extraordinary World of Diamonds (Jacana, Johannesburg, 2010), pp 20, 24-26.

33. Norman, The Extraordinary World of Diamonds, pp 13, 97-98. 
at Du Toit's Pan in 1870 and Kimberley in 1871. His success at Kimberley was shortlived. After two years, a bout of enteric fever forced Du Toit to sell his claim, yet the experience Draper gained here was invaluable. It gave him insight into the geology of how diamonds were formed. Later in his capacity as a geologist, Draper went to the United States to examine a kimberlite intrusion in Kentucky. He also had his name associated with a soft stone found in the Brazilian diamond deposits (called draperite) and contributed papers on diamond deposits in South Africa. ${ }^{34}$ Yet this was all in the future and meanwhile, the failed prospector left Kimberley for the Transvaal - in time for the gold rush. ${ }^{35}$

While officially dated to 1873, the mining of gold in South Africa can be traced as far back as the precolonial era. While the great bulk of the gold supply formed seams deep underground, the actions of weathering and erosion on exposed rock led to small amounts of gold being deposited in rivers and Portuguese traders claim to have traded for gold with indigenous groups living in the Drakensberg. During the Great Trek, Boers under Hendrik Potgieter who arrived in the Soutpansberg found evidence of past mining activity and saw indigenous women adorned with gold and copper jewellery. However, archaeological remnants of precolonial mining activity was subsequently destroyed during the gold rush. ${ }^{36}$ After the formation of the ZuidAfrikaansche Republiek (ZAR), the government reacted to perennial rumours of gold deposits on the Witwatersrand by giving permission to Pieter Jacob Marais to carry out a survey for gold which would be of tremendous economic benefit to the cashstrapped Transvaal republic. Marais, however, focused his attention on searching for alluvial gold and his success was limited. ${ }^{37}$

After the failure of Marais's efforts, excitement was again generated a year later when a German geologist, Karl Gottlieb Mauch was conducting explorations of the southern African interior and discovered evidence of mining activity in Matabeleland. He subsequently discovered a gold deposit near the Tati River in present-day Botswana. This stimulated a gold rush that ultimately fizzled out. ${ }^{38}$ These incidents, however, were simply the precursor to events in 1873 when growing numbers of prospectors flocked to the Transvaal, making the later discovery of gold on the Witwatersrand almost inevitable. The first to strike it rich was Tom McLachlan, a Scottish immigrant, who found gold at Spitskop Hill close to Lydenburg. Strikes were soon made elsewhere but it was only in 1886 with the discovery of the extensive gold deposits on the farm Langlaagte by George Harrison and George Walker that the face of southern Africa was forever transformed. ${ }^{39}$ However, the nature of the deep-level gold deposits on the Witwatersrand soon put paid to the

34. UCT-JL, BC722 Alex L. du Toit Papers F2.10, Obituaries: H.S. Harger, "David Draper, D.Sc", 24 February 1930, pp 25-26.

35. Draper, “An Africander's Reminiscences”, p 50.

36. J. Davenport, Digging Deep: A History of Mining in South Africa (Jonathan Ball, Johannesburg and Cape Town, 2013), pp 72-73.

37. Davenport, Digging Deep, pp 77-78.

38. Davenport, Digging Deep, pp 79-80.

39. Davenport, Digging Deep, pp 86-88, 146-147. 
aspirations of individual prospectors (most of whom were Transvaal burgers) who lacked the necessary capital for the equipment and labour necessary to extract the gold from the conglomerate in which it was found. This promoted the amalgamation of individual claims and eventually the formation of monopolies dominated by mining magnates, many of whom had already made their fortunes in Kimberley. ${ }^{40}$

Along with three compatriots, Draper joined the growing number of alluvial prospectors at Lydenberg goldfields. He did not, however, pin his hopes of striking it rich and took advantage of the opportunities afforded by the burgeoning settlement to engage in a number of occupations ranging from owning a brickyard to selling sewing machines - and instructing the buyers on the use of this new-fangled contraption. ${ }^{41}$ His practical knowledge of diamonds was supplemented with that of gold and it took a trip to Natal to set him on his career path.

Draper's move to Natal was a fortuitous one. He started a business in wool washing and his financial success and stability allowed him to propose marriage to his cousin, Betsy Loxton. The couple were married in 1876 and went on to have five sons, ${ }^{42}$ three of whom became geologists. ${ }^{43}$ Betsy proved a tolerant and faithful spouse, supporting Draper during the highs and lows that were such an integral part of his life. At the end of the South African War, her efforts were partially responsible in gaining Draper's freedom after he had been imprisoned by the British. ${ }^{44}$ After her death in 1908, Draper portrayed her in the tradition of the long-suffering and sacrificing volksmoeder (due to her one-quarter Afrikaner ancestry). The volksmoeder was associated with female Afrikaner patriotism that was expressed through a woman's domestic role as wife and mother. ${ }^{45}$ Betsy Draper had similarly been motivated by her role as wife and mother that, for Draper, was a welcome anachronism in the upheaval of the twentieth century:

Her only object in life was to minister to the happiness of her husband and children and nothing could divert her attention from them. She would never have been induced to adopt modern customs and fashions. She left me with five sons, all men whom any father could be proud of. During her life I had no need to seek for pleasure of entertainment away from my own home. 46

Just as his period in Natal allowed him to acquire a family, it also provided Draper with the environment for the next stage of his life - his career as a geologist. Experiencing both financial and domestic stability for the first time, Draper turned his attention to his long-neglected education. With more disposable income at his

40. Davenport, Digging Deep, pp 154-155.

41. Draper, “An Africander's Reminiscences”, p 51.

42. Draper, "An Africander's Reminiscences”, pp 53, 65.

43. Harger, "David Draper, D.Sc", p 27.

44. Draper, "An Africander's Reminiscences”, p 63.

45. L-M. Kruger, "Gender, Community and Identity: Women and Afrikaner Nationalism in the Volksmoeder Discourse of Die Boerevrou (1919-1931)", MA thesis, University of Cape Town, 1991, p 209.

46. Draper, “An Africander's Reminiscences”, p 65. 
command, he was determined to remedy the deficit in his education and acquire a library of "scientific books". An early purchase was The Principles of Geology by Charles Lyell for 7/6.47 As an introduction to geology, Draper's choice could hardly have been more apt. Lyell and his predecessor, James Hutton, are considered the founders of modern geology. It was Hutton, a figure of the Scottish Enlightenment, who first proposed that all geological formations were a result of ongoing processes observable around us - processes such as weathering, erosion and deposition. ${ }^{48}$ This notion of uniformitarianism or gradual change made a decisive break with the earlier view of catastrophism that was an attempt to marry science to religious thought and proposed catastrophes (such as Noah's flood) as being the key agents for geological change. The figure most associated with uniformitarianism is Charles Lyell.

Born on the family estate in Kinnordy, Scotland in 1797, Lyell studied at Oxford and was elected a member of the Geological Society in London in 1819. A trip to Auvergne in the company of fellow geologist Roderick Impey Murchison (a catastrophist) convinced Lyell of the validity of uniformitarianism. The stratigraphic layers of sedimentary rock at Auvergne were incredibly thin but in total reached a height of some 230 metres indicating an unimaginably long period of steady deposition. ${ }^{49}$ Lyell took an extreme view of uniformitarianism - not only were the geological processes of today the same as those of the past, they had also operated with the same consistency and, as Lyell famously claimed, the "present is the key to the past". ${ }^{50}$ This left no room for catastrophe or sudden, dramatic change. It also presupposed an age of the earth that was far more ancient than had previously been believed. Lyell's views were published in Principles of Geology: An attempt to explain the former changes of the Earth's surface by reference to causes now in operation, a monograph that fascinated a young Charles Darwin aboard the Beagle and it was Lyell's uniformitarianism that gave Darwin the time required for the evolutionary process to occur. ${ }^{51}$

Lyell's Principles somewhat more modestly formed the foundation for Draper's education in geology. Using the book as a reference guide, Draper walked around his farm studying the rock formations until he was able to distinguish sedimentary from igneous rock and developed a rudimentary understanding of the geology of the land. He ventured into the Drakensberg mountains, collecting fossilised plant material that he subsequently sent to the Natural History Museum in London. ${ }^{52}$ And his new-found expertise became lucrative as well.

47. Draper, "An Africander's Reminiscences", p 54.

48. J. Repcheck, The Man Who Found Time: James Hutton and the Discovery of the Earth's Anatomy (Basic Books, New York, 2009), pp 151-158.

49. G. Gohau, A History of Geology, Revised and translated by A.V. Carozzi and M. Carozzi (Rutgers University Press, New Brunswick and London, 1990), p 140.

50. L. Yount, Alfred Wegener: Creator of the Continental Drift Theory (Chelsea House, New York, 2009), p 10.

51. Gohau, A History of Geology, p 139.

52. Draper, “An Africander's Reminiscences”, p 54. 
While on one of his excursions on his farm, Draper noticed a black layer of rock/mud sandwiched between two sandstone strata. He used his penknife to dig out a sample, wrapped it in his handkerchief, took it home and placed it on the stove. The material subsequently ignited and was revealed to be coal. Draper had discovered a coal seam running across his farm. ${ }^{53}$ Coal is formed from the abundance of plant material found in tropical areas. This material accumulates in waterlogged environments and is subject to bacterial action that promotes its decomposition, first into peat and, as a result of the heat and pressure exerted during burial, ultimately into coal. The greater the heat and pressure, the higher the percentage of carbon and, with it, the quality of the material. ${ }^{54}$ The coalfields of what was then northern Natal were part of the Ecca formation that extended into the Transvaal. The seams varied in thickness, in general increasing as they moved further north. The coal was found with shale which would present some confusion for the novice geologist. ${ }^{5}$

Subsequently, Draper began extracting the mineral and supplying it to dealers in Newcastle and Pietermaritzburg. The gaps in his education were evident, however, when it became apparent that he was unable to distinguish coal from shale and an order sent to Pietermaritzburg received the following response: "The stuff you call coal would not burn in Hell", teaching Draper the invaluable lesson that, "everything black is not coal". ${ }^{56}$ Yet before long, Draper began to acquire a reputation for his growing geological expertise and was invited to present a paper before the Society of Newcastle - his first public speaking event that aroused considerable attention with his use of samples to illustrate the geology of northern Natal. ${ }^{57} \mathrm{He}$ was also able to persuade the Natal Government Railways to utilise coal mined in Natal both on the trains and in industry in general, thus stimulating coal mining in the province. ${ }^{58}$

It was a small step from a coal seam in Natal to the gold mines of the Witwatersrand - a decision made relatively easy by the persistent ill-fortune that dogged Draper's attempts at farming, in this case the affliction of his cattle with pleuro-pneumonia and increasing difficulty experienced in wool-washing. Draper left for the Barberton gold fields where there was a feverish gold rush. He worked as a geologist, assisting with tracking the reefs and was eventually made manager of Natalia Company's holding on the Pioneer Reef, Moodie. His success here prompted him to go to Johannesburg where he took up a position at the Compton \& Gardiner Black Reef Mine. ${ }^{59}$ Draper made the transition from amateur geologist walking the fields on his farm, to become part of the goldmining industry that was to underpin the

53. Draper, “An Africander's Reminiscences”, p 54.

54. J.G. Grotzinger and T. Jordan, Understanding Earth (W.H. Freeman, New York, 2010), p 635.

55. A.L. du Toit, The Geology of South Africa (Oliver \& Boyd, Edinburgh and London, 1954), pp 284, 286.

56. Draper, “An Africander's Reminiscences”, p 54.

57. Draper, "An Africander's Reminiscences", p 55.

58. Harger, "David Draper, D.Sc", 24 February 1930, pp 20-21.

59. Draper, “An Africander's Reminiscences”, pp 56-57. 
South African economy, with breath-taking ease, thereby highlighting the opportunities available to the self-made geologist in the late nineteenth century.

Yet, even as Draper embodied the amateur geologist whose expertise was hard-won through fieldwork rather than formal education, he also became an integral figure in the professionalisation of geology. In 1890 on his first trip abroad, Draper struck up a friendship with Dutch geologist, Gustaaf Molengraaff in Amsterdam. ${ }^{60}$ The son of a church minister, Molengraaff had studied at Leiden University and received his doctorate in geology based on his study of the Caribbean island of St Eustatius which was under Dutch control. ${ }^{61}$ At the time of Draper's arrival, Molengraaff was teaching geology at the University of Amsterdam and he travelled to South Africa a year later to study the goldfields. ${ }^{62}$ He renewed his acquaintance with Draper who travelled with him through the Transvaal and took great joy in having his geological knowledge improved by "one who knew how to teach". ${ }^{63}$ A formally trained geologist, Molengraaff acquired expertise in the geology of the region and was appointed as state geologist of the ZAR. He also played a role - alongside Draper - during the South African War in drawing up casualty lists. Upon his return to the Netherlands, Molengraaff wrote the authoritative "Geology of the Transvaal", which was published in 1901, with the English translation appearing three years later. He returned to South Africa on numerous occasions, one of which was to attend the International Geological Congress in 1929; he was also awarded the Draper Medal by the Geological Society of South Africa in $1938 .{ }^{64}$

But just as Draper benefited from Molengraaff's expertise and the Dutch geologist symbolised the status of the university-educated geologist, Draper was also achieving recognition for his own work. After a temporary economic setback on the Witwatersrand mines that saw him losing his investment, he returned to Natal and purchased two farms in the hope of beginning an iron foundry. He therefore went on his second trip to England to learn how to produce iron and steel in Sheffield. It was during this visit that his geological expertise was recognised when he was elected a Fellow of the Geological Society - the first South African to achieve that distinction. In an ironic twist, he also discovered that the foundry in Natal would not be commercially viable, which left him once again teetering on the brink of financial ruin. This necessitated yet another move to the Transvaal where he was hired by the Chamber of Mines to conduct a survey and collect fossils in the area that lay to the north of Pretoria. ${ }^{65}$ Draper's life was a constant attempt to reconcile pragmatic needs with academic desire.

60. Draper, “An Africander's Reminiscences”, p 57.

61. H.A. Brouwer, "Levensbericht van Gustaaf Adolf Frederik Molengraaff (27 Februari 1860-26 Maart 1942)", in Jaarboek, 1941-1942, p 3, at http://www.dwc.knaw.nl/ biografie/pmknaw/?pagetype=authorDetail\&aId=PE00001924, accessed on 13 March 2018.

62. Brouwer, "Levensbericht van Gustaaf Adolf Frederik Molengraaff”, pp 4-5.

63. Draper, “An Africander's Reminiscences”, p 57.

64. Brouwer, "Levensbericht van Gustaaf Adolf Frederik Molengraaff”, pp 5, 8-9.

65. Draper, “An Africander's Reminiscences”, pp 57-59. 
His financial straits temporarily alleviated, Draper focused in greater detail on the academic nature of geology, contributing a number of geological papers to the Geological Society of London. His articles ranged from a descriptive "Geology of South-Eastern Africa" to an assessment of the marble deposits in Natal in terms of their economic value as well as their association with the surrounding rock. ${ }^{66} \mathrm{He}$ also became convinced of the need for the formation of a professional body of geologists so that members could pool their knowledge to the advantage of a rapidly expanding mining industry. The envisaged association would incorporate all those engaged in geological work from the explorer/prospector to the formally trained geologist and the mining engineer. ${ }^{67}$

This was not the first attempt at creating a professional organisation. The South African Geological Association (SAGA) was founded in 1888 but had a short lifespan of only two years. It was formed in reaction to a suggestion made by John Shaw of the South African College on the occasion of the Queen's Jubilee in $1888 .{ }^{68}$ As a largely academic institution, SAGA modelled itself on the first geological society that had been established in London in the first decade of the nineteenth century with a focus on assembling a library of geological knowledge and identifying rock samples sent in by its members. ${ }^{69}$ However SAGA's geographical base in Grahamstown in the Eastern Cape - distant from Kimberley and the Witwatersrand - was emblematic of its inability to meet the requirements of the burgeoning mining industry and the practical applications of economic geology. Nevertheless, seven years later it was reestablished in the economic heart of South Africa - the Witwatersrand. ${ }^{70}$

While Draper was conducting his geological survey of the area north of Pretoria he considered the formation of what was to become the Geological Society of South Africa. In conjunction with like-minded geologists such as Hugh Exton and John Ballot, he worked to make the organisation a reality. ${ }^{71}$ This was achieved on 4 February 1895 when the first meeting of the GSSA took place in the council room of the Transvaal Chamber of Mines in Johannesburg. Hugh Exton was elected the society's first president, John Ballot one of its vice presidents, and David Draper described as the "midwife" who had brought the society into being - became the society's secretary. The GSSA's links to the mining industry were made explicit with the role of honorary president being given to the well-known "randlord", Lionel Phillips, the chairman of the Chamber of Mines. The constitution of the GSSA was adopted from its British antecedent, the Geological Society of London. ${ }^{72}$ At this historic meeting, Draper also presented the first paper before the society, on the topic

66. Harger, "David Draper, D.Sc", pp 20-21.

67. Harger, "David Draper, D.Sc", p 21.

68. C. Plug and G. Levin, "South African Geological Association (1888-1890)", in C.R. Anhaeusser (ed.), A Century of Geological Endeavour in Southern Africa, 1895-1995 (Geological Society of South Africa, Johannesburg, 1997), p 8.

69. See http://www.geolsoc.org.uk/history, accessed on 12 December 2014; Plug and Levin, "South African Geological Association", p 8.

70. Plug and Levin, "South African Geological Association”, p 10.

71. Draper, “An Africander's Reminiscences”, p 59.

72. Anhaeusser (ed.), A Century of Geological Endeavour, p 13. 
of the gold-bearing conglomerate on the Witwatersrand - a subject of great topical interest. ${ }^{73}$ Later, in his capacity as the curator for the Chamber of Mines Museum, Draper was also responsible for persuading the Chamber of Mines to donate its mineral collection to the GSSA, which later formed the core of the museum. ${ }^{74}$

The Cape of Good Hope Geological Survey was also founded in 1895, contributing to the increasing professionalisation of geology in South Africa ${ }^{75}$ - a trend evident in Draper's own career which took on a more overtly professional aspect with the publication of various papers and his role in the GSSA which, in turn, led to increasing work as a mining consultant with "fees [flowing] into [his] bank account". ${ }^{76}$ Yet fate had another setback which would put Draper at odds with the powerful mining interests on the Witwatersrand - and this would be based on principle.

As the son of a British immigrant, Draper's sense of nationalism was complicated and was rendered even more so by the context of the late nineteenth and early twentieth centuries that saw the creation of a new state in southern Africa. While Draper was unequivocal about the sense of a civilising mission and the virtues of colonisation, he was rather more ambivalent about his own identity as part of a British settler population. Draper's father had arrived at the Cape just over a decade after the Cape had been made a British colony and young Draper's early experiences of the colony was one where Dutch was the dominant language and there was simmering tension between English and Afrikaner colonists. This tension was particularly evident in the Eastern Cape where the English resented being governed by the Afrikaners whom they viewed contemptuously as being "illiterate", "conservative" and "anti-progressive". ${ }^{77}$ This was evident in Atherstone's portrayal of the gullibility of the "Karoo Boer" who was persuaded that a fossil was a remnant of the "flood" ${ }^{78}$ Yet, for Draper, the Afrikaans-speakers were independent-minded and self-made colonists who played a significant role in taming the land and making it more productive. They were a hardy people who retained a fierce pride in their culture, religion, customs and way of life - also evident in the characterisation of his wife as a volksmoeder. ${ }^{79}$ These pro-Boer views were strengthened during his time as a storekeeper where he boarded with a family by the name of Du Plessis. ${ }^{80}$ Once had had come of age, he was also part of a Boer commando - as mentioned previously that engaged in action against the Basotho. Draper's affinity with those of Dutch/Afrikaner heritage sat uneasily with his work as an English-speaking geologist who depended on the powerful, profit-seeking mining companies for his livelihood.

73. Harger, "David Draper, D.Sc", p 21.

74. Harger, "David Draper, D.Sc", p 21.

75. S.M. Naudé and A.C. Brown, "The Growth of Scientific Institutions in South Africa", in A.C. Brown (ed.), A History of Scientific Endeavour in South Africa (Royal Society of South Africa, Cape Town, 1977), p 70.

76. Draper, "An Africander's Reminiscences", p 59.

77. Draper, “An Africander's Reminiscences”, p 13.

78. Dubow, A Commonwealth of Knowledge, $\mathrm{p} 104$.

79. Draper, “An Africander's Reminiscences”, p 13.

80. Draper, “An Africander's Reminiscences”, pp 33-34. 
Conflict in the ZAR in the late nineteenth century served to make his position virtually untenable - indicative of the dilemma of identity that accompanied the emergence of this new nation. Yet Draper's response was an unusual one.

Paul Kruger's control of the Transvaal presented a real impediment to the interests of the mining industry as embodied in the person of Cecil John Rhodes. Heavy taxation, the ZAR's concession policy which made the use of the railways and dynamite prohibitively expensive, and the obstacle presented by an independent ZAR to Rhodes' imperial ambitions, provided the necessary impetus for a coup. Supported by the various mining magnates - Lionel Phillips, the head of the Chamber of Mines, Percy Fitzpatrick and George Farrar among others, and with the tacit approval of the British colonial secretary, Joseph Chamberlain - Rhodes and Alfred Beit initiated a plan that would involve the invasion of the ZAR by Dr Leander Starr Jameson. He was to be accompanied by 500 armed policemen of the British South Africa Company in what became known as the Jameson Raid. Unfortunately, this plan did not have the envisaged support among the Uitlanders who were expected to rise up against the Kruger government; Jameson and his invading force were halted and captured. The resulting scandal forced Rhodes to step down as prime minister of the Cape Colony. In the aftermath of the Jameson Raid, Kruger's animosity towards the British increased and he began to stockpile weapons and strengthen his relationship with the Orange Free State - his likely ally in the event of war. In response to his increasing oppression, the Uitlander elite formed the South African League and appealed to Britain to intervene so as to secure their rights in the ZAR - an action that ultimately culminated in the outbreak of war between Britain and the ZAR. ${ }^{81}$

Draper's response to the Jameson Raid was one of outrage: “This misguided and futile attempt on the part of the capitalists to overthrow the Republican Government and erect in its stead an oligarchy of Mining Magnates has brought about more trouble and race hatred than any other event in the history of South Africa." 82 For Draper, the actions of Jameson in the service of men like Rhodes, was an assault on natural liberties for the sake of capital exploitation and Jameson himself was little more than a "freebooter". Draper's heated reaction was to march along with the Boer commandos who took to the streets of Johannesburg to show their solidarity and strength in the wake of Jameson's arrest. ${ }^{83}$

Unsurprisingly, this did not go down well in a society that was rapidly becoming polarised and Draper admits to a loss of work as a mining geologist. Perhaps naively believing in the distinction between science and politics, Draper proceeded to the Imperial Institute in London to present a paper but was unsurprisingly - attacked for his support of the ZAR government. His attempts to read his paper were disrupted until the police were called in to restore order, allowing Draper to finish. Despite a paper focused purely on geology, he was

81. Davenport, Digging Deep, pp 235-239.

82. Draper, “An Africander's Reminiscences", p 59. By "capitalists", Draper meant his employers.

83. Draper, “An Africander's Reminiscences”, p 59. 
subsequently vilified in the British press for putting forward his political views which demonstrated the fraught atmosphere in the country just prior to the outbreak of the South African War. ${ }^{84}$

When open hostilities did break out two years later, Draper viewed it as a product of the mining capitalists who refused to espouse traditional English libertarian virtues, "... the Capitalists had at last succeeded in dragging the fair name of good old England into the mire". 85 This time, Draper was more circumspect in demonstrating his loyalties, compounded by his own uncertainty regarding his nationality. His feelings aroused at the impending war reflected both competing loyalties and the complexities of living in what was to become South Africa. Draper thought through the process carefully - he was the child of English settlers but had pledged his loyalty to his commando unit in the war against the Basotho. He had also become a citizen of the Transvaal. The very title of his unfinished autobiography, "An Africander's Reminiscences", suggests an identity rooted in the African continent. Conflicted, he went so far as to write to the British resident in the Transvaal, Cunningham Green, for clarity. The reply was unequivocal, banishing all doubt Draper's oath of loyalty implied his allegiance and he was therefore no longer considered a British subject. He could join the war effort without being considered a traitor. At the same time, he showed an understandable reticence in actively fighting his fellow English-speakers, preferring instead to involve himself in policing Johannesburg. Subsequently he signed up for the Troyeville division. 86

Draper's skills as a geologist were also required for the war. Since the gold deposits of the Witwatersrand were arguably an accident of geology and that reaping the benefits of gold was a primary motive behind the conflict, it seemed apt that Draper and Molengraaff were called upon in their capacity as geologists. Both men were sent to determine the likelihood of diverting the Malopo River away from Mafeking, thus depriving the town of an important source of water and hastening the end of the siege. Boer troops under General Piet Cronje had besieged the British troops led by Colonel Baden-Powell for more than seven months. ${ }^{87}$ With a letter from the president of the ZAR, Paul Kruger, detailing the plan, the two men met with Cronje who was dismissive of the enterprise: "Return and say to the President, Cronje is a warrior and it is his intention to capture Mafeking with his burghers and he will have nothing to do with cutting off the water supply; return immediately." 88

After the battle of Elaandslaagte which resulted in a British victory in October, 1899,89 Draper joined Cronje as a non-combatant responsible for drawing up casualty lists of dead or wounded soldiers. Portraying himself as a "neutral", he also assisted British forces, helping to bury dead soldiers after the battle of Magersfontein and

84. Draper, “An Africander's Reminiscences”, p 60.

85. Draper, "An Africander's Reminiscences", p 61.

86. Draper, “An Africander's Reminiscences”, p 62.

87. T. Pakenham, The Boer War (Abacus, London, 2003) pp 105, 416.

88. Translated in Draper, “An Africander's Reminiscences", p 62.

89. Pakenham, The Boer War, pp 133-141. 
transporting wounded British soldiers to hospital during the battle of Paardeberg, ${ }^{90}$ which also culminated in Cronje's defeat. ${ }^{91}$ Subsequently he joined General Christiaan De Wet's unit for the duration of the war and surrendered when the British eventually captured Johannesburg in June 1900. Despite taking an oath of neutrality, Draper was made a prisoner of war and held in Ladysmith until his wife's intervention. Betsy Draper produced the letters of gratitude expressed by the British commanders at Magersfontein and Paardeberg and so acquired her husband's release by order of Lord Kitchener. ${ }^{92}$

Upon his release, Draper joined his son, Thomas - also a geologist - in Borneo prospecting for oil for the Shell Transport \& Trading Company. Ill health brought them back to South Africa and once in Durban, Draper affirmed his allegiance to King Edward VII, thus regaining his British citizenship. Initially this did very little to ameliorate his return to Johannesburg and for the first few months he was treated like a pariah for what was perceived to be his treasonous behaviour. Time, however, lessened the hostility and Draper began to prosper again as a geologist due to his invaluable familiarity with the geology of the Transvaal. ${ }^{93}$

Draper's political role, his rejection of the mining magnates and vacillation during this period contests any simplistic notion of the relationship between Boer and Brit. At the same time, it may perhaps also be indicative of class tensions. His own humble origins and hard-won expertise in geology made him place great value on the self-made figure, the very antithesis of powerful mining capitalist interests. His role as a mining geologist, however, made this ideological conflict both a very personal and a professional one.

Even as his political leanings had an adverse effect on his earnings as a geologist, Draper was faced with a far more invidious change in the discipline of geology - the rise of the professional, university-trained geologist who, by virtue of academic background, was given preference over Draper in an industry where big capital sat uneasily with the adventuring prospector, and practical experience was second to academic knowledge. ${ }^{94}$ Draper's concerns also highlighted another important consideration - the pecuniary aspect. Integral to his career as a geologist was his need to earn a living so economic geology and, with it, the location of potentially valuable mineral resources was essential. His financial straits were thus relieved significantly with a discovery of tin ore which gave him a profit of $£ 15000 .{ }^{95}$

It was these financial concerns that were behind Draper's subsequent visit to South America in 1908. He was offered £2 500 along with all travelling expenses to assess the Agua Suja Diamond Mine in Brazil. Upon his arrival, Draper disagreed with the

\footnotetext{
90. Draper, “An Africander's Reminiscences”, p 63.

91. Pakenham, The Boer War, $\mathrm{p} 342$.

92. Draper, “An Africander's Reminiscences”, p 63.

93. Draper, “An Africander's Reminiscences”, pp 63-64.

94. Draper, “An Africander's Reminiscences", p 64.

95. Draper, “An Africander's Reminiscences”, p 64.
} 
Brazilian state geologist over the origin of the diamonds of Brazil. The state geologist believed that they were alluvial while Draper contended that like South African diamonds, they originated in kimberlite or volcanic pipes. ${ }^{96}$ Another visit to Brazil eight years later also saw Draper note the similarities between South African and South American rock types despite the intervening Atlantic Ocean. ${ }^{97}$ It was these similarities, among others, that led to Alex du Toit making the case for continental drift and the connections between South America and Africa less than a decade later. Yet, even as Du Toit is the South African geologist most associated with continental drift, Draper made early reference to the connection between continents two decades before Alfred Wegener received international recognition - and condemnation - for the concept.

In the rather whimsically titled "A Ramble through the Geology of South Africa", Draper wrote of the findings of the Indian geological survey that suggested a connection between India and Africa with the possibility of a submerged continent that had once joined the two landmasses. ${ }^{98}$ Draper drew attention to the similar fossil evidence across the landmasses which he later reinforced by highlighting and comparing the fossil and floral evidence of South America with that of South Africa, positing the existence of a land connection between the two. ${ }^{99}$ Where Draper did differ, however, was that he did not consider the movement of continents but instead hypothesised the existence of land - now submerged - between the continents that had once comprised Gondwana. His awareness of this, however, demonstrated the extent of his interest in geology, and showed the convergence between geology as an intellectual discipline as well as economic geology.

The paper itself demonstrated Draper's love for geology, the passion and enthusiasm that he had for the earth where life both originated and ended. His description of the curious geologist observing and investigating the landscape to determine its make-up and geological history was reminiscent of his journey to Colesberg as a child. Geology also served as a reminder of both the contradictory nature of the eternal and the ephemeral - the awe-inspiring mountains that dominated the skyline would, over the passing of millennia, be subject to the inexorable processes of weathering and erosion to be deposited into the oceans from whence the cycle would begin anew. ${ }^{100}$ For Draper the calling of the geologist lay in discerning a few chapters of the earth's early history and in evoking the lost worlds of the past:

I wish you to accompany me in imagination, into that dim and far-distant period, when in the words of the sacred historian, "The earth was without form and void" - a world incomplete, and in process of construction; and to a period when the plutonic forces were dominant, when the solid portion of the

\footnotetext{
96. Draper, “An Africander's Reminiscences”, p 66.

97. Draper, “An Africander's Reminiscences”, p 70.

98. D. Draper, "A Ramble through the Geology of South Africa", Transactions of the Geological Society of South Africa, Part II, 3 (April 1897), p 28.

99. Harger, "David Draper, D.Sc", p 24.

100. Draper, "A Ramble through the Geology of South Africa”, p 19.
} 
earth's crust were making their first appearance above the surface of a seething ocean, wherein no life existed, and when this sphere was enveloped in a dense atmosphere impenetrable to light, and consequently "Darkness was upon the face of the waters". ${ }^{101}$

The geology of the earth, like the discipline of geology itself, was focused on the creation of order out of chaos. And Draper, in contradiction of the purported divide between science and religion, saw geology as a product of intelligent design even as it was continuously shaped by natural, observable processes. ${ }^{102}$

In a descriptive and poetic narrative, Draper painted an evocative picture of rock formation and exotic life forms, of the geological effects of volcanism and glaciation, of cataclysm and creation that ultimately gave birth to the mineral resources that came eventually to define the southern African economy. ${ }^{103}$ These were linked to his own experiences - the formation of coal beds through the decomposition of plant life, the volcanic action that brought diamond-bearing kimberlite pipes to the surface and the precipitation of gold from ancient oceans. ${ }^{104}$

Draper's final stint in South America saw him managing a coal mine in Brazil. ${ }^{105}$ This trip was, however, even more memorable for becoming Draper's version of a journey into the heart of darkness. Mercer was an English engineer who had been living in Brazil for forty years when Draper met him in 1916. For him, the engineer represented the failure of the civilising mission. Expecting a little bit of England in the midst of Brazil, instead Draper found abominable squalor; Mercer had "gone native" and the result, according to Draper, was appalling:

On the walls were pictures from the Illustrated London News, dating back to 1883, the latest. The old man, badly clad, his long grey beard matted with dirt, his face unwashed ( $\mathrm{p}$ 69) ... At bedtime I was shown into a small dirty room and passed the night in agony. Vermin of many descriptions crawled over my body and kept me awake ... Noticing that there were many coloured people about the house, all bare-footed and ragged and unkempt, I asked him who they were and he said: "They are my children and grandchildren". ${ }^{106}$

Mercer had married his black cook with whom he had numerous offspring and Draper was struck with amusement at the notion of the expatriate visiting his homeland with his family in tow. ${ }^{107}$ Mercer, in a sense, functions as a cautionary tale the antithesis to the idea of progress and taming the landscape (and its indigenous inhabitants) that Draper associated with the Afrikaner and British settlers of southern Africa of which he was also part.

101. Draper, "A Ramble through the Geology of South Africa", p 20.

102. Draper, "A Ramble through the Geology of South Africa", p 29.

103. Draper, "A Ramble through the Geology of South Africa", pp 24-25.

104. Draper, "A Ramble through the Geology of South Africa", pp 20, 25-26.

105. Draper, “An Africander's Reminiscences”, p 71.

106. Draper, “An Africander's Reminiscences”, pp 69-70.

107. Draper, “An Africander's Reminiscences”, p 70. 
After an eventful life, one of Draper's final academic contributions was a manuscript "The Birth of the Diamond Industry in South Africa" that described the early history of diamond mining which Draper had witnessed first-hand. Through the use of his own drawings and words Draper was able to reconstruct a bygone era for an audience far removed from it. ${ }^{108} \mathrm{He}$ had come to symbolise the history of an emerging discipline and a new country. As he said later in jest, "Some people reach the dotage stage; I have got to the anecdotage!"109 In 1927 he was awarded an honorary doctorate in Science from the University of the Witwatersrand, the culmination of lifelong learning. ${ }^{110}$

\section{Conclusion}

In 1932 the David Draper Medal was introduced by the Geological Society of South Africa as a means of paying homage to one of the society's founding members. This, the GSSA's most prestigious award, is presented to geologists who have made a significant contribution to the discipline of geology and to the furtherance of South African geology in particular.111 In 1933, its recipient was Alex du Toit, the academically-trained professional geologist, symbolic of an assertive and clearly defined state - even if the nation remained a contested one based on inclusion and exclusion. On the other hand, through a colourful life embroiled in the defining moments of the country's nascence, David Draper had epitomised the key decades that shaped the state that was destined to be established in 1910 - colonisation, conflict and capitalism, all of which were inseparable from the country's geology.

\section{REFERENCES}

Anhaeusser, C.R. (ed.), A Century of Geological Endeavour in Southern Africa, 18951995 (The Geological Society of South Africa, Johannesburg, 1997).

Barnard, W.S., "Darwin at the Cape", South African Journal of Science, 100 (May/June 2004).

Brouwer, H.A., "Levensbericht van Gustaaf Adolf Frederik Molengraaff (27 Februari 1860-26 Maart 1942)", in Jaarboek, 1941-1942, at http://www.dwc.knaw.nl/ biografie/pmknaw/pagetype=authorDetail\&aId=PE00001924, accessed on 13 March 2018.

Davenport, J., Digging Deep: A History of Mining in South Africa (Jonathan Ball, Johannesburg and Cape Town, 2013).

Draper, D., "A Ramble through the Geology of South Africa", Transactions of the Geological Society of South Africa, Part II, 3 (April 1897).

Dubow, S., A Commonwealth of Knowledge: Science, Sensibility and White South Africa, 1820-2000 (Oxford University Press, Oxford, 2007).

108. Harger, “David Draper, D.Sc", pp 26-27.

109. Harger, "David Draper, D.Sc", p 27.

110. Harger, "David Draper, D.Sc", p 27.

111. Anhaeusser (ed.), A Century of Geological Endeavour, pp 23, 27. 
Dubow, S., "Earth History, Natural History and Prehistory at the Cape", Comparative Studies in Society and History, 46, 1 (January 2004).

Du Toit, A.L., The Geology of South Africa (Oliver \& Boyd, Edinburgh and London, 1954).

Etherington, N., Harries, P. and Mbenga, B.K., "From Colonial Hegemonies to Imperial Conquest, 1840-1880", in Hamilton, C., Mbenga, B.K. and Ross, R. (eds), The Cambridge History of South Africa, Volume 1: From Early Times to 1885 (Cambridge University Press, New York, 2012).

Gohau, G., A History of Geology, Revised and translated by A.V. Carozzi and M. Carozzi (Rutgers University Press, New Brunswick and London, 1990).

Grotzinger, J.G. and Jordan, T., Understanding Earth (W.H. Freeman \& Company, New York, 2010).

Hammel, T., “Thinking with Birds: Mary Elizabeth Barber's Advocacy for Gender Equality in Ornithology", Kronos: Southern African Histories, 41, 1 (2015).

Harger, H.S., Obituary, “David Draper, D.Sc”, 24 February 1930, available at UCT-JL, Alex du Toit Papers BC722.

Draper, D., "An Africander's Reminiscences”, Unpublished and incomplete manuscript available at Johannesburg City Library, J.P.L. Strange Collection MSA777, "Draper - 577728".

Kruger, L. "Gender, Community and Identity: Women and Afrikaner Nationalism in the Volksmoeder Discourse of Die Boerevrou (1919-1931)", MA thesis, University of Cape Town, 1991.

Legassick, M. and Ross, R., "From Slave Economy to Settler Capitalism: The Cape Colony and its Extensions, 1800-1854", in Hamilton, C., Mbenga, B.K. and Ross, R. (eds), The Cambridge History of South Africa, Volume 1: From Early Times to 1885 (Cambridge University Press, New York, 2012).

Livingstone, D., "Debating Darwin at the Cape", Journal of Historical Geography, 52 (2016).

Naudé, S.M. and Brown, A.C., "The Growth of Scientific Institutions in South Africa", in Brown, A.C. (ed.), A History of Scientific Endeavour in South Africa (Royal Society of South Africa, Cape Town, 1977).

Norman, N., The Extraordinary World of Diamonds (Jacana, Johannesburg, 2010).

Pakenham, T., The Boer War (Abacus, London, 2003).

Plug, C. and Levin, G., "South African Geological Association (1888-1890)", in Anhaeusser, C.R. (ed.), A Century of Geological Endeavour in Southern Africa, 1895-1995 (The Geological Society of South Africa, Johannesburg, 1997).

Repcheck, J., The Man Who Found Time: James Hutton and the Discovery of the Earth's Anatomy (Basic Books, New York, 2009).

Rogers, A.W., "The Pioneers in South African Geology and their Work", in Transactions of the Geological Society of South Africa, Annexure to Volume XXXIX (Geological Society of South Africa, Johannesburg, 1937).

Yount, Y., Alfred Wegener: Creator of the Continental Drift Theory (Chelsea House, New York, 2009). 